\title{
Gibberellic acid and water regime in the flowering induction of Brassocattleya and Cattleya hybrid orchids
}

\author{
Jean C Cardoso ${ }^{1}$; Elizabeth O Ono ${ }^{2}$; João D Rodrigues ${ }^{2}$ \\ ${ }^{1}$ Vliet Flora-Setor de Biotecnologia, C. Postal 170, 13825-000 Holambra-SP; ${ }^{2}$ UNESP-IBB, Depto. Botânica, Botucatu-SP; \\ jeancardosoctv@gmail.com; eoono@ibb.unesp.br
}

\begin{abstract}
The influence of gibberellic acid $\left(\mathrm{GA}_{3}\right)$ and water regime was evaluated in the flowering induction and quality of two orchid hybrids belonging to the genera Cattleya $(C$.) and Brassocattleya $(B c$.). The experiment was carried out in the Biotechnology and Orchid Culture Sector of Shunji Nishimura Technology Foundation, Pompéia, São Paulo State, Brazil. Five $\mathrm{GA}_{3}$ concentrations $(0,125,250,500$ and $1,000 \mathrm{mg} \mathrm{L}^{-1}$ ) were tested through four consecutive leaf applications in adult plants that had already flowered at least once, besides two water conditions (one and four irrigations per week). Applications were performed in October and November for $B c$. Marcella Koss and in January and February for $C$. Irene Holguin. Flowering could not be induced in the latter by gibberellic acid. In $B c$. Marcella Koss, the application of $250 \mathrm{mg} \mathrm{L}^{-1} \mathrm{GA}_{3}$ combined with decreased irrigation frequency induced flowering in around $83 \%$ plants. By using the same $\mathrm{GA}_{3}$ concentration but frequent irrigation, only $17 \%$ plants were induced to flower. The number and size of flowers increased after application of higher $\mathrm{GA}_{3}$ concentrations. This work allowed developing a commercial technique with the use of gibberellic acid $\left(\mathrm{GA}_{3}\right)$ to induce flowering in $B c$. Marcella Koss hybrid orchid.
\end{abstract}

Keywords: Ornamental plants, flowering, quality, pulverization, plant growth regulator, water suppression.

\section{RESUMO}

Ácido giberélico e regime hídrico na indução do florescimento de orquídeas Brassocattleya e Cattleya híbridas

No presente trabalho foi avaliada a influência do ácido giberélico e do regime hídrico na indução e qualidade do florescimento de duas orquídeas híbridas dos gêneros Cattleya $(C$.) e Brassocattleya $(B c$.). $\mathrm{O}$ experimento foi realizado no Setor de Biotecnologia e Orquidicultura da Fundação Shunji Nishimura de Tecnologia, Pompéia-SP. Foram testadas cinco concentrações de $\mathrm{GA}_{3}(0,125,250,500$ e $1.000 \mathrm{mg}$ $\left.\mathrm{L}^{-1}\right)$ em quatro aplicações consecutivas via pulverização foliar, em plantas adultas que já haviam florescido ao menos uma vez, além de duas condições hídricas (uma e quatro irrigações por semana). As aplicações foram feitas nos meses de outubro e novembro para $B c$. Marcella Koss e janeiro e fevereiro para $C$. Irene Holguin. Não foi possível induzir a floração em Cattleya Irene Holguin com o uso de ácido giberélico. Para $B c$. Marcella Koss, a aplicação de $250 \mathrm{mg} \mathrm{L}^{-1}$ de $\mathrm{GA}_{3}$, associado à diminuição na frequência de irrigação, induziu cerca de $83 \%$ das plantas ao florescimento. Na mesma concentração de $\mathrm{GA}_{3}$, porém em condições de irrigação frequente, apenas $17 \%$ das plantas foram induzidas a florescer. O número e o tamanho das flores aumentaram com a aplicação de concentrações maiores de $\mathrm{GA}_{3}$ utilizadas no experimento. A realização deste trabalho permitiu desenvolver uma técnica comercial com o uso de ácido giberélico $\left(\mathrm{GA}_{3}\right)$ para a indução do florescimento do híbrido de orquídea $B c$. Marcella Koss.

Palavras-chave: Plantas ornamentais, floração, qualidade, pulverização, regulador vegetal, supressão de água.

(Recebido para publicação em 19 de outubro de 2009; aceito em 19 de agosto de 2010) (Received on October 19, 2009; accepted on August 19, 2010)

$\mathrm{T}$ he progressive increase in Brazilian flower production aimed at the internal and external market is linked to the growth of investments in technology by producers in general who act in the sector of flowers and ornamental plants. Exportation of Brazilian floriculture products summed US\$31.5 millions in 2009; however, importation in the sector (US\$20 millions) remain high (Kyiuna et al., 2010). Orchids still have small participation in this total but present an annual increase of more than $100 \%$ in exportation and domestic market in addition to a huge potential, especially for external market (Junqueira \& Peetz, 2008).
The family Orchidaceae has more than 30,000 species and thousands of hybrids originated in several countries, from places at sea level to the highest points of Colombia, Chile, Ecuador, Venezuela, Peru and others, from marshes to arid regions, and from extremely hot regions to places where snow is frequent (Suttleworth et al., 1994). All these differences make difficult the establishment of a single cultivation technique for the large quantity of species, resulting in the specialization of orchid producers.

Among orchids, the genus Cattleya, including its intergeneric hybrids, is one of the most attractive for the market due to its high genetic variability and production of flowers presenting attractive size, shape and colors. However, the first flowering of this genus is longer, which delays commercialization and increases production costs. In addition, with some exceptions, it presents lush flowering only once a year, with 7 to 30 days of flower durability (Cardoso \& Israel, 2005).

According to Sheenan (1992), the group Cattleya is divided into two types as to flowering habit: Cattleya gigas, which produces new sprouts in the spring and flowers in the summer, each sprout flowering separately; and Cattleya trianaei, which produces 
sprouts in the spring but does not flower before autumn. In this period, spathes become dry and all originated sprouts flower simultaneously. These flowering features are transmitted to descendant hybrids of crossbreeding involving such species. The second group can be photoperiodically manipulated and flowers twice a year.

Although the number of researches involving ornamental species has currently increased, most of them focus on the nutrition of species (Amaral et al., 2009) and cultivars (Ludwig et al., 2008; Villas Bôas et al., 2008), and few current studies have investigated plant growth regulators and their effect on flowering induction and quality.

Gibberellins are biochemically described as tetracyclic diterpene acids and are associated with flowering induction in several species. When exogenously applied, these plant growth regulators lead to petal growth and flowering induction in long-day plants under conditions of short days. The opposite can occur in some exceptions (Cid, 2000).

Philodendron cv. Black Cardinal plants were induced to flower under noninductive conditions through application of gibberellic acid $\left(\mathrm{GA}_{3}\right)$ at 125, 250, 500 and $1,000 \mathrm{mg} \mathrm{L}^{-1}$, increasing flowering percentage and inflorescence number per plant with increasing concentrations (Chen et al., 2003). In flower cultivation, other species have their flowering induced by $\mathrm{GA}_{3}$ applied via pulverization, such as Dieffenbachia (Henny, 1980), Zantedeschia (Corr \& Widmer, 1987) and Anthurium (Henny \& Hamilton, 1992).

Chen et al. (1997) reported that flowering can be induced in Phalaenopsis cv. Leda with the application of $\mathrm{GA}_{3}$ under conditions of high temperatures, non-inductive to flowering.

Several species are induced to flower after a period of drought or lower rainfall (Taiz \& Zeiger, 2004). As examples, coffee (Drinnan \& Menzel, 1995), citrus (Ribeiro et al., 2006) and orchids of the genus Cattleya (Cardoso \& Israel, 2005) can be mentioned.

The aim of this work was to evaluate the effect of water regime and gibberellic acid at different concentrations on the induction and quality of off-season flowering in Cattleya and Brassocattleya orchids.

\section{MATERIAL AND METHODS}

The experiment was carried out in the nursery of Shunji Nishimura Technology Foundation, located in Pompéia municipality, São Paulo State, Brazil, along 12 months between 2005 and 2006.

As plant material, two hybrids originated from the cultivation of shoot tips were used. The first tested hybrid was Cattleya Irene Holguin, which flowers in August/September and presents intense pink flowers and pink/ yellow labellum. Extensively used in orchid trade for flower production, this hybrid originates sprouts with spathes between October and February, which remain dormant during short days, and its flowering occurs once in this time gap. The second tested hybrid was Brassocattleya Marcella Koss, which flowers in May and June. This intergeneric hybrid between Brassavola and Cattleya has light pink flowers and pink/yellow labellum and produces new sprouts throughout the year, which may or may not present spathes. In the non-inductive season, even sprouts with spathes do not produce flowers, and the flower bud dies before starting the normal flowering season. Therefore, only sprouts originated from March and April can flower. All plants had mean age of 6 years and 8-10 pseudobulbs each.

Plants were grown in hothouses of plastic and protected with $70 \%$ shade. Fertilization was interspersed at every week, using $1 \mathrm{~g} \mathrm{~L}^{-1}$ of N-P-K formulations, $15-15-20$ and 20-10-10, complemented with S (4\%), Ca (1.10\%), $\mathrm{Mg}(0.40 \%), \mathrm{Fe}(0.10 \%), \mathrm{Zn}(0.07 \%)$, $\mathrm{Mn}(0.06 \%), \mathrm{B}(0.05 \%), \mathrm{Cu}(0.05 \%)$ and Mo $(0.02 \%)$. The cultivation substrate consisted of tree fern fiber at $75 \%$ and Pinus barks number 2 to $25 \%$. Tree fern fiber was employed since pots had already been used for cultivation during four years, when it was still the main substrate employed for many ornamental species, including orchids. For plant cultivation, black plastic pots n.15 were used.

Besides control, treatments consisted of four $\mathrm{GA}_{3}$ concentrations (125, 250, 500 and $1,000 \mathrm{mg} \mathrm{L}^{-1}$ ) sprayed on leaves four times, and two irrigation conditions, totaling ten treatments designed in randomized blocks and in $5 \times 2$ factorial arrangement. Three blocks containing two plants each were used, totaling six plants per treatment.

$\mathrm{GA}_{3}$ presenting a minimum of $95 \%$ purity was diluted in $4 \mathrm{~mL}$ hydrated alcohol at $92.8^{\circ} \mathrm{GL}$, and $0.1 \%$ Tween $20^{\circledR}$ (Ethoxylated Sorbitan Monolaurate (nonionic surfactant)) was added to this solution before completing it with water. Controls were treated with water plus Tween $20^{\circledR} 0.1 \%$.

Pulverizations were performed in October and November 2005 for $B c$. Marcella Koss and in January and February 2006 for $C$. Irene Holguin, between 7 and 8 a.m., when the relative humidity is higher, favoring the product uptake. For this procedure, a knapsack mistblower $\left(20 \mathrm{~L}\right.$, Jacto $\left.^{\circledR}\right)$ attached to an $\mathrm{X}_{2}$ conical nozzle was used, separating control plants in order to prevent contamination with residues. Around $70 \mathrm{~mL}$ solution was sprayed per plant on both leaf surfaces and in young roots, with 7-day interval between applications.

As to water regime, two irrigation conditions were adopted. In the first regime, irrigation was done four times a week through microsprinklers, whereas in the second one, plants were subjected to decreased irrigation frequency; thus, they were kept for 15 days without irrigation, followed by irrigation only once a week, also through microsprinklers. In the latter case, $\mathrm{GA}_{3}$ applications started soon after 15 days without irrigation.

The effects of plant growth regulator and irrigation frequency were investigated considering aspects of flower production, such as flowering rate $(\%)$, number of flowered plants relative to the total used in each treatment, number of inflorescences and flowers obtained in the respective treatments, number of flowers per plant and diameter of flowers and petals of flowered plants (cm) by using a millimeter rule. Plants that did not flower received the value 0 
to allow mean comparison tests, since the absence of flowering was considered a consequence of treatments and not of lost plots.

The results were subjected to analysis of variance ( $\mathrm{F}$ test) and means compared according to Tukey's test at $5 \%$ significance. The obtained flowering rates were subjected to regression analysis to evaluate the effect of $\mathrm{GA}_{3}$ levels. All statistical analyses were done by using the software SAS, following the user's guide SAS/STAT (1990).

\section{RESULTS AND DISCUSSION}

There was no flowering induction in Cattleya Irene Holguin plants subjected to $\mathrm{GA}_{3}$ application under non-inductive conditions, although high concentrations were used (four consecutive pulverizations of 1,000 $\left.\mathrm{mg} \mathrm{L}^{-1} \mathrm{GA}_{3}\right)$. The change in water regime to a situation of lower water availability did not affect flowering in that hybrid, even when $\mathrm{GA}_{3}$ was concomitantly sprayed. In addition, $\mathrm{GA}_{3}$ did not prevent flowering during the normal season when applied in July at concentrations up to $1,000 \mathrm{mg} \mathrm{L}^{-1}$. These results lead to the conclusion that $\mathrm{GA}_{3}$ application combined or not with water availability did not influence Cattleya Irene Holguin flowering.

Taiz \& Zeiger (2004) reported that gibberellins can replace the requirement of long days for flowering in several species, stimulating flowering in some plants, but not in others.

$\mathrm{GA}_{3}$ application between October and November induced flowering in Brassocattleya Marcella Koss plants during October, November, December and January, making such process earlier. According to Taiz \& Zeiger (2004), exogenous application of gibberellins can lead to floral evocation in few short-day species under non-inductive conditions and in plants requiring cold to flower.

Both $\mathrm{GA}_{3}$ concentrations and water stress affected flowering rate in $B c$. Marcella Koss (Figure 1). Under more frequent irrigation, the highest flowering rate $(33 \%)$ was obtained after four applications of $1,000 \mathrm{mg} \mathrm{L}^{-1}$. Lower

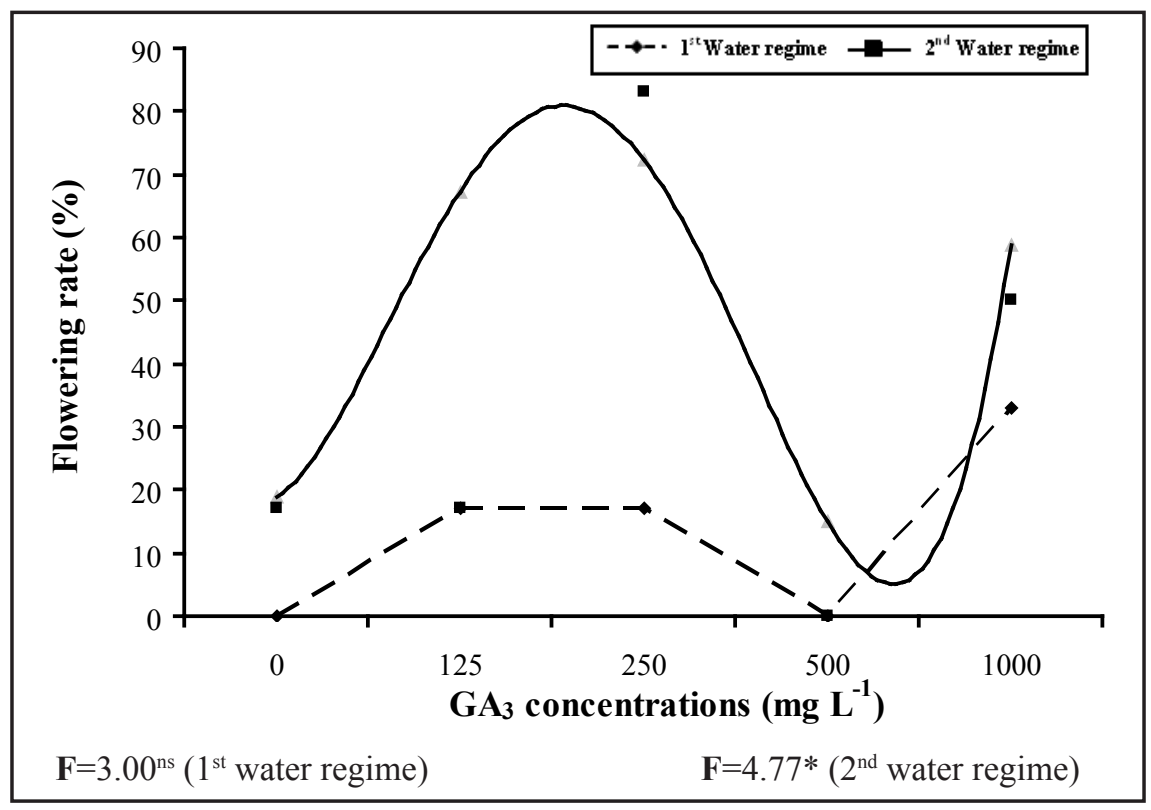

Figure 1. Flowering rate in Brassocattleya Marcella Koss plants treated with 0, 125, 250, 500 and $1,000 \mathrm{mg} \mathrm{L}^{-1}$ gibberellic acid $\left(\mathrm{GA}_{3}\right)$ and subjected to two water regimes (one and four irrigations a week) (taxas de florescimento de Brassocattleya 'Marcela Koss' tratadas com $0,125,250,500$ e $1.000 \mathrm{mg} \mathrm{L}^{-1}$ de ácido giberélico $\left(\mathrm{GA}_{3}\right)$ e duas condições hídricas (uma e quatro irrigações por semana)). Pompéia, FSNT, 2006.

*First water regime: No significance for regression; Second water regime: $\mathrm{y}=0.00000131 \mathrm{x}^{3}$ $-0.00187 x^{2}+0.6 x+18.84 . R^{2}=0.54$

irrigation frequency combined with $\mathrm{GA}_{3}$ applications increased flowering rate in that hybrid, especially when four applications of $250 \mathrm{mg} \mathrm{L}^{-1} \mathrm{GA}_{3}$ were combined with the second water regime, inducing flowering in around $83 \%$ plants (Figure 1). No flowering was detected under $\mathrm{GA}_{3}$ application at $500 \mathrm{mg} \mathrm{L}^{-1}$. These results reveal the need of water deficit and gibberellic acid at suitable concentration to induce flowering in plants, due to the synergistic effect between the tested factors.

Such variations in flowering rate under different $\mathrm{GA}_{3}$ concentrations may be related to the multifactorial control model of flowering, explaining the differences among results from experiments involving application of plant growth regulators (Davies, 1995; Coll et al., 2003). In several commercial species, flowering induction requires more than one exogenous factor acting together. In coffee (Coffea arabica L.), low temperatures are needed to induce flower buds. However, when the photoperiod is longer than $13 \mathrm{~h}$, inflorescences do not develop even under low temperatures (Drinnan \& Menzel, 1995). Yamanishi (1995) reported a larger number of inflorescences and flower buds in pomelo (Citrus grandis) plants under low temperatures and trunk strangulation. The increased number of inflorescences and flowers was preceded by an increase in $\mathrm{C} / \mathrm{N}$ ratio of pomelo leaves.

Control plants of $B c$. Marcella Koss did not flower under frequent irrigation. $\mathrm{GA}_{3}$ application increased the number of flowers per plant, which was one flower/plant after treatment with the highest concentration $\left(1,000 \mathrm{mg} \mathrm{L}^{-1}\right)$. Less frequent irrigations combined with $\mathrm{GA}_{3}$ applications increased that number to 1.67 flowers/plant when this regulator was sprayed at $250 \mathrm{mg} \mathrm{L}^{-1}$. These results lead to the conclusion that both gibberellic acid and low water availability are extremely important for a high-quality flowering in such orchid.

Philodendron 'Black Cardinal' plants were also induced to flower under noninductive conditions after application of $\mathrm{GA}_{3}$ at 125, 250, 500 and 1,000 mg $\mathrm{L}^{-1}$, with increased flowering percentage and number of inflorescences per plant according to higher $\mathrm{GA}_{3}$ concentrations (Chen et al., 2003).

Flower diameter increased with higher $\mathrm{GA}_{3}$ concentrations (Table 1). The 
Table 1. Mean diameter of flowers and petals of Brassocattleya Marcella Koss plants treated with $0,125,250,500$ and 1,000 $\mathrm{mg} \mathrm{L}^{-1} \mathrm{GA}_{3}$ and subjected to two water regimes (one and four irrigations a week) (diâmetro médio das flores e pétalas de Brassocattleya 'Marcela Koss' tratadas com 0, 125, 250, 500 e $1.000 \mathrm{mg} \mathrm{L}^{-1}$ de $\mathrm{GA}_{3}$ e duas condições hídricas (uma e quatro irrigações por semana)). Pompéia, FSNT, 2006.

\begin{tabular}{llcllll}
\hline \multirow{2}{*}{$\begin{array}{l}\mathbf{G A}_{3} \text { concentrations } \\
(\mathbf{m g ~ L}\end{array}$} & \multicolumn{2}{c}{)} & \multicolumn{2}{c}{ Flowers $\varnothing(\mathbf{c m})$} & & \multicolumn{2}{c}{ Petals $\varnothing(\mathbf{c m})$} \\
\cline { 2 - 3 } \cline { 6 - 7 } & $\begin{array}{c}\mathbf{1}^{\text {st }} \text { water } \\
\text { regime }\end{array}$ & $\begin{array}{c}\mathbf{2}^{\text {nd }} \text { water } \\
\text { regime }\end{array}$ & & $\begin{array}{c}\mathbf{1}^{\text {st }} \text { water } \\
\text { regime }\end{array}$ & $\begin{array}{c}\mathbf{2}^{\text {nd }} \text { water } \\
\text { regime }\end{array}$ \\
\hline 0 & $0.00 \mathrm{C}$ & $3.83 \mathrm{BC}$ & & $0.00 \mathrm{C}$ & $2.07 \mathrm{BC}$ \\
125 & $3.76 \mathrm{BC}$ & $4.08 \mathrm{AB}$ & & $1.83 \mathrm{BC}$ & $1.83 \mathrm{BC}$ \\
250 & $3.92 \mathrm{AB}$ & $11.75 \mathrm{~A}$ & & $1.93 \mathrm{BC}$ & $5.87 \mathrm{~A}$ \\
500 & $0.00 \mathrm{C}$ & $0.00 \mathrm{C}$ & & $0.00 \mathrm{C}$ & $0.00 \mathrm{C}$ \\
1,000 & $9.17 \mathrm{AB}$ & $12.50 \mathrm{~A}$ & & $4.13 \mathrm{AB}$ & $6.07 \mathrm{~A}$ \\
\hline $\mathrm{CV}(\%)$ & 45.34 & 30.07 & & 41.36 & 33.21 \\
\hline
\end{tabular}

*Means followed by the same letter in the same column did not differ according to Tukey's test at 5\% significance (médias seguidas pela mesma letra não diferem entre si pelo teste de Tukey em 5\% de probabilidade).

largest diameter $(12.5 \mathrm{~cm})$ was detected after four applications of $1,000 \mathrm{mg} \mathrm{L}^{-1}$ under low water availability, whereas under high availability this value was $9.17 \mathrm{~cm}$. Petal diameter also increased with higher $\mathrm{GA}_{3}$ concentrations, and the highest value was obtained at $1,000 \mathrm{mg} \mathrm{L}^{-1}$. Visually, flowers did not lose quality, keeping harmony, petal and sepal organization and flowering uniformity. Low mean values estimated for flowers and petals, even under the best treatments, were due to the absence of flowering in some plants, to which the value 0 was attributed.

Pulverization of gibberellic acid $\left(\mathrm{GA}_{3}\right)$ combined with water stress can be used on commercial scale to induce flowering in some orchid hybrids. This occurs because such a product has high aggregated value and low application cost, around $\mathrm{R} \$ 0.24 /$ plant. In $B c$. Marcella Koss, four applications of 250 $\mathrm{mg} \mathrm{L}^{-1} \mathrm{GA}_{3}$ at 7-day intervals combined with lower irrigation frequency induced flowering under unfavorable conditions, allowing an efficient flowering control. Besides, gibberellic acid increased the number of flowers per plant without influencing flowering quality. Hybrids correlated to $B c$. Marcella Koss, such as $B c$. Pastoral and $B c$. Pink Debutante, commercially important in orchid culture, likely present the same physiological response to $\mathrm{GA}_{3}$. However, these and other hybrids should be separately tested, considering their genetic and physiological characteristics.

\section{ACKNOWLEDGEMENTS}

We thank Professors Elizabeth Orika Ono and João Domingos Rodrigues for the immeasurable assistance in the elaboration and execution of this study, and Professors Carmen SF Boaro, Norberto Silva and Armando R Tavares. We also thank the Shunji Nishimura Technology Foundation for the structure provided to this work.

\section{REFERENCES}

CARDOSO JC; ISRAEL M. 2005. Levantamento de espécies da família Orchidaceae em Águas de Sta. Bárbara-SP e seu cutlivo. Horticultura Brasileira 23: 169-173.

CHEN WS; CHANG HW; CHEN WH; LIN YS. 1997. Gibberellic acid and cytokinin affect Phalaenopsis flower morphology at high temperature. HortScience 32: 1069-1073.

CHEN J; HENNY RJ; MCCONNELL DB; CALDWELL RD. 2003. Gibberellic acid affects growth and flowering of Philodendron 'Black Cardinal'. Plant Growth Regulation 41: 1-6.

CID LPB. 2000. Introdução aos hormônios vegetais. Brasília: Embrapa-CENARGEN, $180 \mathrm{p}$.

COLL JB; RODRIGO GN; GARCÍABS; TOMÉS RS. 2003. Fisiología Vegetal. Madrid: Ed. Pirámide. 566p.
CORR BE; WIDMER RE. 1987. Gibberellic acid increases flower number in Zantedeschia elliottiana and Z. rehmannii. HortScience 22: 605-607.

DAVIES PJ. 1995. Plant hormones: Physiology, Biochemistry and Molecular Biology. Dordrecht: $2^{\mathrm{a}}$ Edithion, Kluwer Academic Publishers. 833p.

DO AMARAL TL; JASMIN JM; NAHOUM PI; FREITAS CB; SALES CS. 2009. Adubação nitrogenada e potássica de bromeliáceas cultivadas em fibra de coco e esterco bovino. Horticultura Brasileira 27: 286-289.

DRINNAN JE; MENZEL CM. 1995. Temperature affects vegetative growth and flowering of coffee (Coffea arabica L.). The Journal of Horticultural Science 70: 25-34.

HENNY RJ. 1980. Gibberellic acid (GA $)$ induces flowering in Dieffenbachia maculata 'Perfection'. HortScience 15: 613.

HENNY RJ; HAMILTON RL. 1992. Flowering of Anthurium following treatment with gibberellic acid. HortScience 27: 1328.

JUNQUEIRA AH; PEETZ MS. 2008. Análise conjuntural das exportações de flores e plantas ornamentais do Brasil. Disponível em http:// www.portaldoagronegocio.com.br. Acessado em outubro de 2008.

KIYUNA I; ANGELO JA; COELHO PJ. 2010. Comércio exterior da floricultura brasileira em 2009: ponto de inflexão. Análises e Indicadores do Agronegócio 5. Disponível em http://www.iea.sp.gov.br/out/verTexto. php?codTexto=11881. Acessado em junho de 2010 .

LUDWIG F; FERNANDES DM; MOTA PRD; VILLAS BÔAS RL. 2008. Macronutrientes em cultivares de gérbera sob dois níveis de fertirrigação. Horticultura Brasileira 26: 68-73.

RIBEIRO RV; MACHADO EC; BRUNINI O. 2006. Ocorrência de condições ambientais para a indução do florescimento de laranjeiras no Estado de São Paulo. Revista Brasileira de Fruticultura 28: 247-253.

SAS Institute. 1990. SAS/STAT. User's Guide. Version $6,4^{\text {th }}$ ed. Cary, NC, USA, v.2, 846p.

SHEENAN TJ. 1992. AOS Solutions. American Orchid Society Bulletin 61: 703-704.

SUTTLEWORTH FS; ZIM HS; DILLON GW. 1994. Orquídeas: Guia dos orquidófilos. Rio de Janeiro: Ed. Expressão e Cultura. 158 p.

TAIZ L; ZEIGER E. 2004. Fisiologia Vegetal. Porto Alegre: Artmed. 719p.

VILLAS BÔAS RL; GODOY LJG; BACKES C; LIMA, CP; FERNANDES DM. 2008. Exportação de nutrientes e qualidade de cultivares de rosa em campo e em ambiente protegido. Horticultura Brasileira 26: 515519.

YAMANISHI OK. 1995. Trunk strangulation and winter heating effects on carbohydrate and its relation with flowering, fruiting and yield of 'Tosa Buntan' pummelo grown in a plastic house. The Journal of Horticulture Science 70: 85-95. 